\title{
Adoption du manioc par les Vili et Yombé du Congo. Innovations culinaires
}

Esther Katz

\section{(2) OpenEdition}

\section{Journals}

Édition électronique

URL : https://journals.openedition.org/tc/405

DOI : $10.4000 /$ tc. 405

ISSN : 1952-420X

Éditeur

Éditions de l'EHESS

\section{Édition imprimée}

Date de publication : 1 avril 1999

ISSN : 0248-6016

\section{Référence électronique}

Esther Katz, «Adoption du manioc par les Vili et Yombé du Congo. Innovations culinaires », Techniques \& Culture [En ligne], 31-32 | 1999, mis en ligne le 26 octobre 2005, consulté le 29 septembre 2022.

URL : http://journals.openedition.org/tc/405; DOI : https://doi.org/10.4000/tc.405

Ce document a été généré automatiquement le 29 septembre 2022.

Tous droits réservés 


\section{Adoption du manioc par les Vili et Yombé du Congo. Innovations culinaires}

Esther Katz 